\title{
Review of Effective Human Resource Management Techniques in Agile Software Project Management
}

\author{
Geshwaree Huzooree \\ Department of IT \\ Charles Telfair Institute \\ Moka, Mauritius
}

\author{
Vimla Devi Ramdoo \\ Dept. of Computer Science and Engineering \\ University of Mauritius \\ Réduit, Mauritius
}

\begin{abstract}
Agile-driven human resource approaches are a departure from plan-driven traditional human resource management approaches. Moreover, research and surveys have shown that adopting agile human resource methodologies are an efficient way of excelling in agile software project management with significant advantages in production costs, time-to-market, complexity, and quality improvement over traditional human resource management methodologies. This paper reviews how effective human resource management techniques that can be applied to agile software project management core challenges. Drawing information from the literature issues like framework for agile organizational change and adoption strategies are examined. Data gathered from the organizations suggest that most of them are best suited in adopting new human resource management techniques. In a nutshell, human resource agility drives organizations to sustain a promising paradigm based on lessons learned towards going agile in software project management.
\end{abstract}

\section{General Terms}

Human resource management, agile software project management.

\section{Keywords}

Human resource management, software project management, agile software project management, traditional human resource, agility-oriented human resource

\section{INTRODUCTION}

The principle behind resource management is to invest in resources as stored capabilities, then unleash the capabilities as and when needed. On the other hand, human resource with the right attitude and correct behavior is considered to be the most important asset in an organization. Therefore strategies must result in tactics that provide the Right Human Resource, in Right Amount, and at the Right Time.

In today's world, organization's business landscape is fastpaced and competitive, and project life cycles are shorter. This emphasize on speed and innovation forces teams to make quick decisions, often in an environment of uncertainty, thus leading to frequent changes in direction and project requirements. Human resource need to be light on their feet, they need to be agile!

Technical teams know that it is impossible to precisely plan new discoveries far in advance, thereby resisting traditional management techniques being cumbersome and not as effective. While many companies have spent significant money and energy customizing common management techniques to their specific situations, they are still finding that is it more of an art than a science.

The core function of Human Resource (HR) is to facilitate and improve organizational agility on top of traditional techniques, that changes HR's mission and focus on Software Project Management. Driving agility means driving HR techniques which create adaptability, competitive advantage, innovation, collaboration, and speed in managing software projects.

\section{LITERATURE REVIEW}

Agile methods are highly prevalent across the community where progressively more organizations are unable to ignore this "agile wave" [1]. The growing popularity of agile methods is clearly evident and "agile techniques are fast becoming the adopted methodology commercially" [2]. Organizations are continuously looking to develop rigorous approaches to manage HR to ensure robust business cases and tangible Return of Investment (ROI).

Research has shown that traditional HR techniques are not well equipped to cope with the ever-changing world of agile software project management, so a new era of agile approach is emerging since early 2010 up to now, showing that it is becoming a priority for Human Resource Management (HRM) to review its traditional techniques and move towards more agile approaches. The aim is to achieve high in terms of excellence and effectiveness.

\subsection{Traditional HRM Model}

The traditional HRM approach focuses on personnel functions such as planning, recruitment and selection, socialization, performance appraisals, some employee-centric development initiatives such as training and development interventions, and motivation initiatives [3]. According to the article of Scheid in 2011[4], two examples of traditional HRM models are described (see Table 1):

Table 1. Traditional HRM Models [4]

\begin{tabular}{|l|l|}
\hline \multicolumn{1}{|c|}{ Industrial Model } & \multicolumn{1}{|c|}{ Salaried Model } \\
\hline $\begin{array}{l}\text { It details workplace rules } \\
\text { and procedures mainly } \\
\text { for factory workers that } \\
\text { are narrow as it contains } \\
\text { rigid job definitions. It is } \\
\text { constrained by less rigid rules and terms } \\
\text { of employment mainly used for } \\
\text { white-collar jobs. But only top } \\
\text { managers are considered } \\
\text { competent to take major } \\
\text { Jobs have no security and } \\
\text { are controlled by } \\
\text { unionism as provisions } \\
\text { for seniority. }\end{array}$ & $\begin{array}{l}\text { jobs, greater job becurity and it } \\
\text { is usually seen as non-union. It } \\
\text { emphasizes less on seniority } \\
\text { and more on merit in deciding } \\
\text { promotions. }\end{array}$ \\
\hline
\end{tabular}

\subsection{Agile Model for HRM}

The Agile HR is acquiring its ground very quickly in the software project management world. Organizations are craving to possess an HRM which is strategic, proactive and has a high-level of influential expertise. Moreover, it should 
clearly focus on creating high business value in terms of flexibility and scalability.

According to the organization Bersin and Associates in 2012 [4] [5], agile HRM strategies have been devised to support organizations that are going agile on software project management as follows:

- Ensuring that all the leaders in the company are trained as hands-on-coach instead of managers.

- Re-structure the employees into smaller self-managed teams to ensure better productivity.

- Ensuring effective and fluid interactions among all the stakeholders.

- Conveying a clear and concise mission, vision and values to everyone.

- Ensure transparency of information concerning project goals and stakeholders involvement during system development.

- Ensure proper team planning for effective teamwork, sharing of information and project management among team members.

- Emphasize on continuous learning throughout the organization.

- Create a good branding for the organization to attract talented people.

- Recruit skilled, knowledgeable and professional people.

- Empower and motivate people to provide proper and genuine feedback.

- Create rewards and recognition program for employees.

- Design programs to ensure team diversity.

The Agile Model of HR represents the thinking of lean, adopted by the Toyota Production System (Toyota - the largest car manufacturer in 2007) and the Agile Manifesto [6] to the business practices. It is the new, emerging way HR defines its mission.

\subsection{AEHN's Agility-Oriented Human Resource Strategy Framework}

In order to bring organizational agility, AEHN [7] [8] found that five interrelation HR initiatives were very important. These five main components resulted into AEHN's agilityoriented human resource strategy framework as follows:

\subsubsection{Achieving Contextual Clarity}

AEHN went to great lengths to assure that employees at all levels:

- Clearly understood the dynamic and threatening nature of the environment facing the healthcare industry.

- Fully grasped the vision for the organization.

- Regularly tracked the organization's progress.

- Could see and articulate a link between their individual and collective actions and the performance of the total enterprise. This promotes tactics for survival in an agile organization through workshops, training, transparent communication.

\subsubsection{Embedding Core Values}

According to Scott Ambler in 2002, to be able to cope in an agile software project, human resources should possess core values [9] as follows:

- Communication: between stakeholders and the team members as well as between the developers of the team.

- Simplicity: use of easy means to understand the concept (e.g. use diagrams instead of lines of codes).

- Feedback: by communicating all ideas to easily gain feedback.

- Courage: making important decisions.

- Humility: be humble enough to accept that each individual do not know everything.

A research carried out by Shafer et al. in 2000, showed that Albert Einstein Healthcare Network (AEHN), anticipates a tumultuous and largely unpredictable period in its industry by undertaking to convert the organization from one that was basically stable and complacent to one that was agile. AEHN's considered its business strategy and organization design, but focuses primarily on the human resource strategy that emerged over time to foster the successful attainment of organizational agility [7] [8].

Below a list of AEHN core values of human resources [7] [8]:

- Team members are compassionate.

- A Hallmark of Professionalism.

- Team members insist on ever-higher quality.

- Team members rely on each other.

Accordingly, embedding and sustaining the core values became the central human resource initiative in AEHN's drive to agility.

\subsubsection{Enriching Work}

Ensuring that all the HR of the organization is working according to the three general principles:

- $\quad$ Aligned with the broad behavioral outcomes of initiate, adapt, and deliver.

- Consistent with the core values.

- Expanded to develop and utilize multiple competencies.

\subsubsection{Promoting Personal Growth}

Through this initiative AEHN hoped to reach the point where all employees were taking personal responsibility for their own development, not only to enhance performance in current assignments, but to be future-oriented, as personal growth reinforces the agility challenge.

\subsubsection{Providing commensurate returns}

AEHN sought to provide all employees with intrinsic and extrinsic rewards according to increasing contributions to the organization. The organization ensured that fairness and equity were maintained to promote organizational agility.

\section{TECHNIQUES COMPARISON}

Surveys concerning the adoption of agile processes have been conducted from 2005 to 2008 by different research institutions. According to Schwaber and Fichera, 14\% of North American and European organizations have adopted agile processes in 2005 with a further $19 \%$ either interested or planning to do so in the future [2]. In 2007, Ambler research 
showed that out of 600 participants, $69 \%$ had adopted agile techniques with an additional $7.3 \%$ believing that agile would be adopted within a year [10]. In 2008, Vijayasarathy and Turk's survey confirmed that out of 98 respondents, $60 \%$ is use agile approaches in $75 \%$ or more of their projects [11]. Based on the trends of the survey results, agile processes are quickly gaining ground in the organizations.

In 2005, Boehm and Turner discuss business process conflicts between agile and traditional projects. In relation to human resources they outline how "agile development team members often cross the boundaries between standard development position descriptions and might require significantly more skills and experience to adequately perform" [12].

\subsection{Description of diverse approaches to HRM}

An analysis of the literature shows that agile environments are significantly different in context to environments where more traditional approaches are used [1] [9] [13] [14] [6]. Moreover, the Bersin and Associates strategies and AEHN Agile Framework [7] [8] highlighted some major importance towards Agile HRM. Table 2 describes the fundamental HRM techniques.

Table 2. Description of fundamental HRM techniques

\begin{tabular}{|c|c|c|c|c|}
\hline & $\begin{array}{l}\text { HRM } \\
\text { Techniques }\end{array}$ & Traditional HRM & $\begin{array}{l}\text { Agile HRM according to Bersin } \\
\text { Factors }\end{array}$ & AEHN Agile Framework \\
\hline 1 & $\begin{array}{l}\text { Goals and } \\
\text { objectives }\end{array}$ & $\begin{array}{l}\text { Communicated to } \mathrm{HR} \\
\text { across the hierarchy in a } \\
\text { traditional way leading } \\
\text { to silo effect. }\end{array}$ & $\begin{array}{l}\text { There is a system of engagement in } \\
\text { place that brings collaboration among } \\
\text { HR, information sharing and project } \\
\text { management. A focus is built on } \\
\text { continuous learning that changes the } \\
\text { organizational culture. }\end{array}$ & $\begin{array}{l}\text { Goals and objectives are communicated } \\
\text { in such a way that employees clearly } \\
\text { understood the dynamic and threatening } \\
\text { nature of the environment, fully grasp the } \\
\text { organizational vision and regularly track } \\
\text { organization's progress. }\end{array}$ \\
\hline 2 & Recruitment & $\begin{array}{l}\text { Staff are acquired and } \\
\text { managed according to } \\
\text { the project plan and } \\
\text { schedule. }\end{array}$ & $\begin{array}{l}\text { The focus is to attract the right people } \\
\text { and hiring experts instead of general } \\
\text { managers. }\end{array}$ & $\begin{array}{l}\text { AEHN added a half-day session to the } \\
\text { new recruits' orientation program to } \\
\text { explain and demonstrate the meaning of } \\
\text { the core values. }\end{array}$ \\
\hline 3 & $\begin{array}{l}\text { Development } \\
\text { planning }\end{array}$ & $\begin{array}{l}\text { Team building is } \\
\text { conducted through } \\
\text { activities to enhance and } \\
\text { boost confidence. }\end{array}$ & $\begin{array}{l}\text { An ongoing coaching relationship } \\
\text { aligned with leadership builds an } \\
\text { agile framework whereby constant } \\
\text { participatory decision-making results } \\
\text { in team unity and high morale. } \\
\text { Moreover, the team members set their } \\
\text { own targets leading to high- } \\
\text { performance. }\end{array}$ & $\begin{array}{l}\text { Critical development training was done } \\
\text { the agile way, which is on the job, on the } \\
\text { fly while maintaining quality. Personal } \\
\text { growth was encouraged to ensure that } \\
\text { employees stay well ahead on the } \\
\text { learning curve. Development needs are } \\
\text { always identified through a process for } \\
\text { tracking proficiency in technical } \\
\text { competencies. }\end{array}$ \\
\hline 4 & $\begin{array}{l}\text { Training and } \\
\text { certification }\end{array}$ & $\begin{array}{l}\text { Team building exercises } \\
\text { and training sessions are } \\
\text { conducted to enhance } \\
\text { and boost confidence. }\end{array}$ & $\begin{array}{l}\text { Training leaders at all levels of the } \\
\text { company to act as a hands-on coach, } \\
\text { not a "manager" hence developing } \\
\text { programs to foster diversity in teams. }\end{array}$ & $\begin{array}{l}\text { Real-time workshops and "brown bag } \\
\text { sessions" became standard fare to help } \\
\text { employees keep abreast of rapidly } \\
\text { emerging developments. }\end{array}$ \\
\hline 5 & Communication & $\begin{array}{l}\text { Regular interaction with } \\
\text { the members on the } \\
\text { team. }\end{array}$ & $\begin{array}{l}\text { Agile framework aids in the } \\
\text { continuous improvement and } \\
\text { involvement of all team members } \\
\text { through effective communication and } \\
\text { transparency using tactics such as } \\
\text { scrum. Information flow is } \\
\text { transparent in the organization: what } \\
\text { are the goals, who are working on } \\
\text { what project, who are the experts. }\end{array}$ & $\begin{array}{l}\text { Employees make use of a rubric } \\
\text { "Surround Communication", bulletin } \\
\text { boards, newsletters, special forums and } \\
\text { focused training sessions to deliver } \\
\text { information with an unusually high level } \\
\text { of intensity. Use of "Tooling-up Expos" } \\
\text { regrouped employees to interact. }\end{array}$ \\
\hline
\end{tabular}




\begin{tabular}{|c|c|c|c|c|}
\hline 6 & $\begin{array}{l}\text { Performance } \\
\text { appraisals }\end{array}$ & $\begin{array}{l}\text { Annual assessments } \\
\text { conducted on team } \\
\text { performance. }\end{array}$ & $\begin{array}{l}\text { Encouraging and teaching people to } \\
\text { give each other direct feedback for } \\
\text { self-improvement and to build a } \\
\text { performance culture. }\end{array}$ & $\begin{array}{l}\text { Focus is heavily on behavioral } \\
\text { manifestations of the core values, as well } \\
\text { as demonstrations of technical and } \\
\text { managerial competencies and desired } \\
\text { results. A voluntary } 360 \text {-degree feedback } \\
\text { process is instituted to assist supervisors } \\
\text { and managers in assessing behavior- } \\
\text { values gaps and to provide } \\
\text { developmental tools and coaching where } \\
\text { needed. }\end{array}$ \\
\hline 7 & $\begin{array}{l}\text { Rewards and } \\
\text { bonuses }\end{array}$ & $\begin{array}{l}\text { Actions to take on a } \\
\text { member are defined in } \\
\text { advance to distinguish } \\
\text { their performance, } \\
\text { whether up to or below } \\
\text { the level of the project } \\
\text { expectations. }\end{array}$ & $\begin{array}{l}\text { Continuous social recognition } \\
\text { whereby team members and the } \\
\text { leader focus on all areas in need of } \\
\text { improvement; more of peer-to-peer } \\
\text { rewards and recognition. }\end{array}$ & $\begin{array}{l}\text { Relatively marginal changes were made } \\
\text { that was adjusted in the performance } \\
\text { appraisal method. Promotion procedures } \\
\text { are aligned to ensure that living the core } \\
\text { values become a de facto hurdle for } \\
\text { individuals being considered for } \\
\text { promotion to or through supervisory or } \\
\text { managerial positions. }\end{array}$ \\
\hline 8 & $\begin{array}{l}\text { Employee } \\
\text { engagement and } \\
\text { motivation }\end{array}$ & $\begin{array}{l}\text { Motivation is provided } \\
\text { through the standard } \\
\text { means, which are } \\
\text { rewards, punishment or } \\
\text { recognition. }\end{array}$ & $\begin{array}{l}\text { Employee engagement is improved } \\
\text { through open blogs and continuous } \\
\text { feedbacks whereby team members } \\
\text { feel free and are motivated by their } \\
\text { own interests. Customer interactions } \\
\text { are created within all groups and } \\
\text { functions in the company thereby } \\
\text { delivering a strong, focused mission } \\
\text { and values to keep everyone aligned. }\end{array}$ & $\begin{array}{l}\text { A career planning process is developed to } \\
\text { provide templates, tools, and resources } \\
\text { (including coaches) to help employees } \\
\text { clarify career aspirations, identify } \\
\text { competency gaps, and develop } \\
\text { development plans. }\end{array}$ \\
\hline
\end{tabular}

\subsection{Comparison of Diverse Approaches to HRM}

The eight broad categories of the HRM techniques have been divided further into different criteria based on the description in Table 2 [15] [16] [17] [18]. A checklist is used to assess if the HRM technique meet the defined criteria with the aim to evaluate which framework among the three proves to be more suitable to adapt to organizational agility. The eight categories and the criteria are as follows:

\subsubsection{Goals and Objectives}

- Stakeholder collaboration

- Information sharing

- Project management

- Continuous learning

- Awareness of dynamic and threatening environment nature

- Organizational vision

\subsubsection{Recruitment}

- Recruit staff on demands

- Attract right people

- Integrate core values of organization

\subsubsection{Development Planning}

- Team building activities

- Ongoing coaching

- Critical development training

- Focus on quality

- Ensure personal growth

- Track proficiency in technical competencies

\subsubsection{Training and Certification}

- Team building exercises
- Training sessions

- Real time workshop

- Brown bag sessions

\subsubsection{Communication}

- Regular interaction

- Stakeholder involvement

- Transparent information flow through scrum

- Employee rubric

- Bulletin boards, newsletters, special forums and focused training are in place sessions

\subsubsection{Performance Appraisals}

- Annual assessments

- Direct Feedback for performance culture

- 360-degree feedback process

- Provide developmental tools and coaching

\subsubsection{Rewards and Bonuses}

- Rewards are defined in advance

- Continuous social recognition

- Promotion procedures

\subsubsection{Employee engagement and motivation}

- Employee get rewards, punishment or recognition

- Open blogs and continuous feedbacks

- Career planning process to help employees clarify career aspirations, identify competency gaps, and develop development plans 


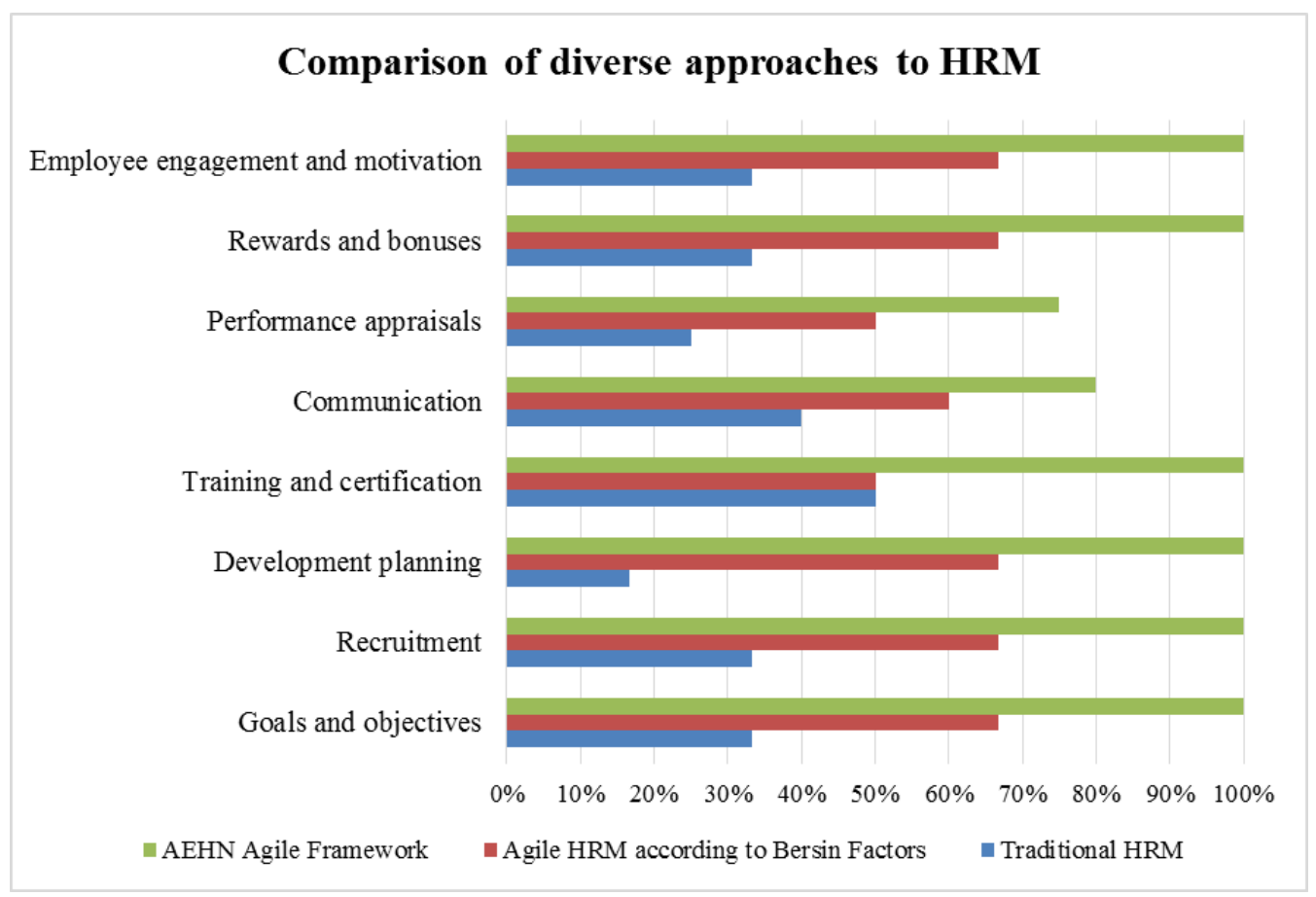

Fig 1: Comparison of the three techniques

\section{RESULTS AND DISCUSSIONS}

Agile software development goal is to produce working software despite changing requirements and environment. Human resource, the major asset of the organization, maintains the top-most priority in order to achieve this goal. Thus HR values needs to be in-built so as to be effective in an agile software project management as there is a need to compete in increasingly dynamic environments that requires new paradigms to replace the mature models that dominate much of today's thinking about business strategies and organizations. Following the research, some lessons have been learned, which are as follows:

- Even in the most dynamic environment, not everything can be emergent.

- Organizational agility doesn't just happen; it has to be deliberately pursued.

- Guiding models facilitate the formation of an agilityoriented human resource strategy.

- A limited number of integrated human resource initiatives define an agility-oriented human resource strategy.

- Key human resource initiatives guide the choice of human resource programs and practices.

The next priority is the management methodology used to effectively manage an agile software project. The traditional waterfall model faces major shortcomings in this case, so there is an urge to replace it by iterations that will bring continuous improvement on a day-to-day basis, both for the HR and project. Moreover, it is worth noting that the traditional HRM is not eliminated in agile, but rather tweaked to perform its best in an agile working environment. For example, the technical comparison shows that in agile organizations, HR are encouraged and teach to give each other direct feedback, as compared to the traditional manageremployee appraisal system.

So, it remains to be seen to what extent, if at all, the comparison techniques of the three major approaches hold up across methodologies, enterprises, and be sustainable. At this juncture, it can be seen that AEHN's framework proves to be more suitable to adapt to this rapidly changing world in the active pursuit of organizational agility as far as software project management is concerned as it encompasses almost all the strategies of Bersin and Associates' Agile HR factors (see Figure 1).

\section{CONCLUSION}

Organizations are quite reluctant to leap towards new human resource management techniques in agile software project management due to the widespread use of traditional HRM. In order to gain competitive edge in the rapid market evolution, it is of utmost importance to adopt organizational change management through new HRM methodologies such as agile HR practices. However, organizations still need solid proof and successful stories of this methodology being advantageous and thus any informal study is likely to be rejected. The question of agile practices crossing the traditional boundaries is still open. If agile experts and management professionals considers this methodology to be promising in the agile software project management, then organizations might be more keen to adopt the concept of agility. This transformation will take years as research is still on-going, and it is possible that during this period other promising technologies may arise and challenge the agility paradigm.

Finally the success of HR agile adoption is directly related to how the new methodologies are introduced in the organization's software project management. A future work for this paper is to conduct a survey on multiple organizations' that are currently working on agile software projects. Based on the survey and research, new frameworks 
and strategies can be proposed with regards to the effective HR management in an agile software development world.

\section{REFERENCES}

[1] Hirani, K. 2012. Project Human Resources Management.

[2] Schwaber, Carey, and Richard Fichera. 2005. Corporate IT leads the second wave of agile adoption. Forrester Research, Inc.

[3] Nerur, Sridhar, RadhaKanta Mahapatra, and George Mangalaraj. 2005. Challenges of migrating to agile methodologies. Communications of the ACM 48.5: 7278.

[4] Bersin, Josh. 2012. Big data in HR. Building a Competitive Talent Analytics Function-The Four Stages of Maturity. Bersin \& Associates.

[5] Bersin, Josh. 2012. The Agile Model comes to Management, Learning, and Human Resources. Bersin \& Associates.

[6] Hazrati, V. 2009. Resource Management in Agile Projects.

[7] Shafer, R.A., Dyer, L., Kilty, J., Amos, J., Ericksen, G. A. 2000. Crafting A Human Resource Strategy To Foster Organizational Agility: A Case Study. CAHRS Working Paper Series, Paper 87.

[8] Shafer, Richard A., et al. 2001. Crafting a human resource strategy to foster organizational agility: A case study. Human Resource Management 40.3: 197-211.
[9] Ambler, Scott. 2002. Agile modeling: effective practices for extreme programming and the unified process. John Wiley \& Sons.

[10] Conboy, K., Coyle, S. 2009. People Over Process: The Implications of Agile for IS Skills and Human Resource Management. IEEE Software, 28. 48 - 57.

[11] Vijayasarathy, L. E. O. R., and Dan Turk. 2008. Agile software development: A survey of early adopters. Journal of Information Technology Management 19.2: 1-

[12] Boehm, Barry, and Richard Turner. 2005. Management challenges to implementing agile processes in traditional development organizations. Software, IEEE 22.5: 30-39.

[13] Augustine, Sanjiv. 2005. Managing agile projects. Prentice Hall PTR.

[14] Chin, Gary. 2004. Agile project management: how to succeed in the face of changing project requirements AMACOM Div American Mgmt Assn.

[15] Fowler, Martin, and Jim Highsmith. 2001. The agile manifesto. Software Development 9.8: 28-35.

[16] Hirani, K. 2009. The impact of Agile practices on Human Resource Management.

[17] Scheid, J. 2011. A Traditional Approach to Human Resource Management.

[18] Tan, C. H. and H. H. Teo. 2007. Training Future Software Developers to Acquire Agile Development Skills. Communications of the ACM 50(12): 97. 